RAZPRAVE

\title{
(NE)VIDNE SPREMEMBE PODEŽELSKIH SKUPNOSTI: PRIMERI Z GORENJSKE IN SAUERLANDA
}

\author{
AVTORJA \\ Erik Logar \\ Vrtna pot 6, Voglje, SI - 4208 Šenčur, Slovenija; logarerik@gmail.com \\ dr. Irma Potočnik Slavič \\ Univerza v Ljubljani, Filozofska fakulteta, Oddelek za geografijo, Aškerčeva cesta 2, SI - 1000 Ljubljana, \\ Slovenija; irma.potocnik@ff.uni-lj.si
}

DOI: $10.3986 / G V 88202$

UDK: $711.3(497.4+430)$

COBISS 1.01

\section{IZVLEČEK}

(Ne)vidne spremembe podeželskih skupnosti: primeri z Gorenjske in Sauerlanda

Podeželska skupnost se kot družbeni in simbolni konstrukt ter hkrati tudi kot enota absolutnega prostora spreminja pod vplivom družbenogospodarskega razvoja. Prispevek obravnava spreminjanje šestih podeželskih skupnosti na vitalnem podeželju $z$ vidika vloge druženja in sodelovanja prebivalcev $v$ treh civilizacijskih stopnjah na izbranih primerih $z$ Gorenjske (Slovenija) in Sauerlanda (Nemčija). (Ne)vidne spremembe znotraj izbranih podeželskih skupnosti so proučevane s primerjalno analizo na podlagi kvantitativnih in kvalitativnih metod, s katerimi so opazovani lažje (migracije, prostori druženja) in težje merljivi (možnost izbire, povečana heterogenost) kazalci sprememb podeželske skupnosti. Geografska analiza sprememb v podeželskih skupnostih je pokazala na njihovo povečano mobilnost, raztočnost ter sobivanje tradicionalnosti, alternativ in novosti pri druženju in sodelovanju.

\section{KLJUČNE BESEDE}

podeželje, podeželska skupnost, Gorenjska, Sauerland, Slovenija, Nemčija

\section{ABSTRACT}

(In)visible changes of rural communities: examples from Gorenjska region (Slovenia) and Sauerland (Germany)

Socioeconomic development has changed the rural community as a social and symbolic construct, and a unit of space as well. This paper discusses six changing vital, rural communities from the social perspective and cooperation. Three case studies surveyed are in Gorenjska region (Slovenia) and three in Sauerland (Germany) throughout the agrarian, industrial and information period. Comparative analysis is based on quantitative and qualitative methods that enabled us to observe (in)visible changes inside selected rural communities. We employed tangible (migration, geography) and intangible indicators (possibility of choice, increased heterogeneity). Geographical analysis of changing rural communities pointed out their increased mobility, bifurcation, co-existence of tradition, alternatives and novelties within formal and informal settings.

\section{KEY WORDS}

rural areas, rural community, Gorenjska region, Sauerland, Slovenia, Germany

Uredništvo je prispevek prejelo 7. septembra 2016. 


\section{Uvod}

V zadnjih sto letih se je zaradi družbenogospodarskega razvoja korenito spremenil način življenja na podeželju. Klemenčič $(2006,161)$ v spremembah zunanjega videza in funkcij podeželskih naselij prepoznava zgolj vidni del mnogo obsežnejših družbenogospodarskih sprememb, v katere so vpete tam živeče skupnosti. McLuhan (2015) trdi, da se danes namesto lokalne skupnosti, za katero je značilen neposreden medsebojni odnos in tesna soodvisnost z okoljem, oblikuje skupnost z močno prepletenimi posrednimi (virtualnimi) človeškimi odnosi in dinamičnim kroženjem (ne)materialnih tokov na planetarni ravni. Kljub temu marsikdo ob besedi "podeželje« pomisli tudi na "povezano, neanonimno, številčno in prostorsko manjšo ter nasploh nadvse prijetno podeželsko (lokalno) skupnost«. Tovrstne predstave o idilični podeželski skupnosti so miselni konstrukt, ki ga je mogoče postaviti v kontekst razkoraka med vse daljšim delovnim časom, čedalje bolj globalizirano, uniformirano svetovno družbo ter pogosto izraženo željo posameznikov po mirnem in sproščenem življenju v stiku z naravo (Woods 2011). Pretirano poenostavljanje predstav o delovanju podeželskih skupnosti in pomanjkanje védenja o spreminjanju podeželskih skupnosti $\mathrm{v}$ sedanjem času spodbuja $\mathrm{k}$ proučevanju podeželja ter podeželskih skupnosti v Sloveniji in tujini.

Prispevek se osredinja na spreminjanje izbranih podeželskih skupnosti v Sloveniji in Nemčiji skozi prizmo treh civilizacijskih stopenj (agrarna, industrijska, informacijska). (Ne)vidne spremembe so analizirane $\mathrm{z}$ vidika medsebojnega druženja in sodelovanja prebivalcev kot ključnega elementa podeželske skupnosti. Proučevanje in razumevanje ključnih razvojnih procesov v podeželski skupnosti je bistveno pri krepitvi njihovih endogenih potencialov in usmerjanju razvoja podeželja.

$\mathrm{V}$ prvem delu prispevka so opisana teoretska izhodišča pri proučevanju podeželske skupnosti in njenega spreminjanja. Sledi metodološka zasnova raziskave $s$ kriteriji za izbor proučevanih podeželskih skupnosti. S pomočjo štirih kazalcev so v tretjem delu prikazane vidne in nevidne spremembe podeželskih skupnosti ter tudi njihova kompleksna prepletenost. Sledita sklep in navedba uporabljenih virov in literature.

\section{Opredelitev problema}

\subsection{K opredelitvi podeželja}

Kot podeželsko skupnost običajno opredeljujemo skupnost ljudi, ki živi na podeželju. Tu prihajamo do prve dileme in sicer, kako opredeliti podeželje? Kvantitativne opredelitve podeželja, ki temeljijo na merljivih in vidnih kazalcih (na primer gostota poselitve, delež kmečkega prebivalstva, delež gozdnih zemljišč), so pogosto primerne le za določen tip podeželja ali za ozek namen raziskave (na primer za pripravo določenega ukrepa znotraj politike razvoja podeželja). Opredelitve podeželja kljub nekaterim pomanjkljivostim (na primer izbor lažje merljivih kazalcev, prevladujoča uporaba aritmetične sredine kot pokazatelja »normalnega« stanja) postopoma vključujejo več kazalcev (običajno vodilnega in dopolnilne) in zahtevnejše statistične metode (na primer multivariantna analiza variance, faktorska analiza). Kljub nakazanim izboljšavam pa so obstoječe opredelitve podeželja še vedno zelo skromen in popačen ter necelovit prikaz dejanskih razmer in procesov na podeželju. Raziskovalci soglašajo, da je pravzaprav nemogoče izoblikovati enotno opredelitev podeželja, ki bi bila uporabna povsod (svet, celina, država; Rowles 1988; Halfacree 1993) in bi bila časovno trajna. Zato je smiselno k opredeljevanju podeželja pristopiti s kvalitativne strani (na primer s spoznavnimi zemljevidi; Guštin 2014), kar nakazuje tudi Halfacreejev (2006) model trozložnega razumevanja podeželskega prostora, sestavljen iz: materialnega prostora, miselnih prostorskih predstav o vsakdanjem življenju in uradnih predstav o prostoru. Materialni prostor se oblikuje s procesi (tokovi, součinkovanje), povezanimi s proizvodnimi in potrošnimi dejavnostmi na "podeželju«. Miselne prostorske predstave o vsakdanjem življenju 
na "podeželju « nastajajo z oblikovanjem podob in simbolov. Uradne predstave o prostoru so uradna pojmovanja o "podeželju «, ki so jih oblikovali snovalci razvojnih politik, politiki, uradniki, planerji in raziskovalci ter interesi kapitala; običajno so izmišljene in abstraktne (Klemenčič 2006, 163). Med temi sestavnimi deli obstajajo stalne napetosti, kar ustvarja dinamiko v podeželskem prostoru, nudi možnosti za prestrukturiranje podeželja in oblikuje prostor za umeščanje politike razvoja podeželja.

Halfacreejev pogled nas tako usmerja k preseganju dualizma v razumevanju in dojemanju (podeželskega) prostora kot konkretnega, materialnega, geografskega prostora na eni strani, ter imaginarnega prostora kot stanja duha, idej in simbolov na drugi strani. To nas vodi k razmišljanju, da pravzaprav ni napačno, če se raziskovalci s pomočjo raznovrstnih kvalitativnih (ali kombiniranih kvalitativno-kvantitativnih) pristopov bolj približujemo razumevanju realnega stanja na podeželju; seveda ob upoštevanju objektivnega dejstva, da vseh stvari ne moremo natančno izmeriti, razmejiti in pojasniti. Opredeljevanje podeželja v praksi je takšno delovno področje, kjer nam pretirana kvantifikacija onemogoča razpoznavanje vidnih in težje razumljivih znakov sprememb, kar posledično vodi tudi v manj ustrezno interpretacijo procesov, ki potekajo na podeželju. Na podeželju namreč obstajajo tudi očem nevidne povezave, ki ustvarjajo kompleksnost podeželja. V opredelitvah podeželja takšnih nevidnih povezav ni, ker jih je težko proučevati (so na primer nemerljive), ker je njihovo proučevanje dolgotrajno (na primer procesi, ki potekajo dlje časa), ker jih ne razumemo (na primer odnosov med akterji) ali pa jih še ne poznamo (Guštin 2016).

Dilemo o opredelitvi podeželja poskušamo v prispevku preseči s tem, da empirični del raziskave poteka na območjih, ki jih je politika v razvojnih programih prepoznala za "podeželska« (s kvantitativnimi kazalci), katerih proizvodni in potrošni tokovi izkazujejo značaj "podeželskosti«, ter jih njihovi prebivalci v miselnih predstavah zaznavajo kot "podeželske«. Zavedamo se, da tudi tovrsten pristop nikakor ne omogoča univerzalne opredelitve podeželja oziroma obče veljavnega vrednotenja pojavov in procesov na podeželju. Njegova prednost je v tem, da skuša zaobiti preveliko posploševanje in poenostavljanje ter se približati dejanskim razmeram na "podeželju«. Velika težava pri uporabi tega pristopa je v pomanjkanju podatkov, odsotnosti njihovih daljših časovnih vrst ter precejšnji odvisnosti od prevladujočih kvalitativnih podatkov, pri čemer je možna tudi večja verjetnost subjektivnosti pri interpretaciji rezultatov.

\subsection{O konceptualizaciji skupnosti}

Ob priznavanju pojasnjevalne moči Halfacreejevega trozložnega modela podeželja »trčimo« ob drugo dilemo - kako opredeliti skupnost? Liepinsova (2000) trdi, da veliko raziskav nekritično uporablja pojem skupnosti, ne da bi se pri tem zavedali njene kompleksnosti. V slovenskem jeziku se pogosto uporablja besedna zveza »lokalna skupnost«, ki jo mnogi uporabljajo kot sinonim za (podeželsko) skupnost in pri tem vnašajo nejasnosti. Lokalna skupnost je nosilec lokalne samouprave, ki je priznana $\mathrm{z}$ ustavo (Ustava ... 2016, 9. člen) in ostalim pravnim redom (Zakon o lokalni ... 2007). Navedeni zakon v 1. členu določa občine kot temeljne samoupravne lokalne skupnosti. Lokalna skupnost je organizirana skupina ljudi, ki sama odloča o svojih, lokalnih zadevah. Ta dikcija potrjuje Halfacreejevo izhodišče, da so uradne predstave sestavni del konceptualizacije (podeželskega) prostora. Do nejasnosti v zakonodaji pride ob določilu, da se »... mestne občine delijo na mestne četrti oziroma četrtne skupnosti, medtem ko se občine delijo na lokalne skupnosti, naselja oziroma krajevne skupnosti (Zakon o lokalni ... 2007). Ker je v Sloveniji 11 mestnih občin, je tako za 201 občino predvideno, da ima »lokalne skupnosti«.

Opredelitvi skupnosti so veliko pozornosti namenjali ruralni sociologi, ki so se naslonili na ugotovitve Tönniesa (Woods 2011): le-ta je pojem skupnosti (nemško Gemeischaft) in družbe (Gesellschaft) opredelil na podlagi oblik družbene interakcije (medsebojnega učinkovanja). Skupnost je tako pojmoval kot združevanje ljudi, temelječe na vzajemnih povezavah, občutku skupnosti in skupnih ciljih; te značilnosti so pripisovali tradicionalnemu podeželskemu prostoru, ki naj bi ga odlikovale stabilne in povezane skupnosti. Liepinsova (2000) opisuje te zgodnje poskuse konceptualizacije (podeželske) skupnosti kot 
zapadanje v strukturno-funkcionalni ali pa v etnografski pristop. Strukturno-funkcionalni pristop prepoznava skupnost kot relativno ločen in stabilen pojav z značilnostmi, ki jih lahko opazujemo (strukture); tovrstne raziskave so opazovale in beležile pričakovane strukturne značilnosti. Raziskave, ki so vključevale etnografski pristop, so skušale dokumentirati resnične prakse skupnosti s skrbnim beleženjem »avtentičnih« izkušenj in odnosov. Zaradi pomanjkljivosti sta bila oba pristopa izpostavljena kritikam, da so te konceptualizacije »opisne, statične, tradicionalne, neznanstvene, pred-moderne (Liepins 2000). Ker je bil tako pojem skupnosti »oropan« pojasnjevalne moči, se je skupnost uporabljala v raziskavah podeželja le kot opisni pojem oziroma kot »označba obsega raziskave (lokalna raven) ali občutka družbene kolektivnosti«. Šele s kulturnim preobratom v osemdesetih in devetdesetih letih 20. stoletja se je v raziskavah podeželja ponovno povečal interes za proučevanje pomena skupnosti, kar je bilo vidno v vzniku novega pristopa, ki je konceptualiziral skupnost kot simbolni in družbeni konstrukt (Liepins 2000; Halfacree 2006; Klemenčič, Lampič in Potočnik Slavič 2006; Klemenčič in sod. 2008; Potočnik Slavič 2010; Woods 2011).

\subsection{Podeželska skupnost}

Prek poskusov opredelitve podeželja in skupnosti se postopno približujemo osrednji temi naše raziskave - podeželski skupnosti. Koncept podeželske skupnosti (angleško rural community) je tradicionalno

Slika 1: Elementi podeželske skupnosti (prirejeno po Liepins 2000).

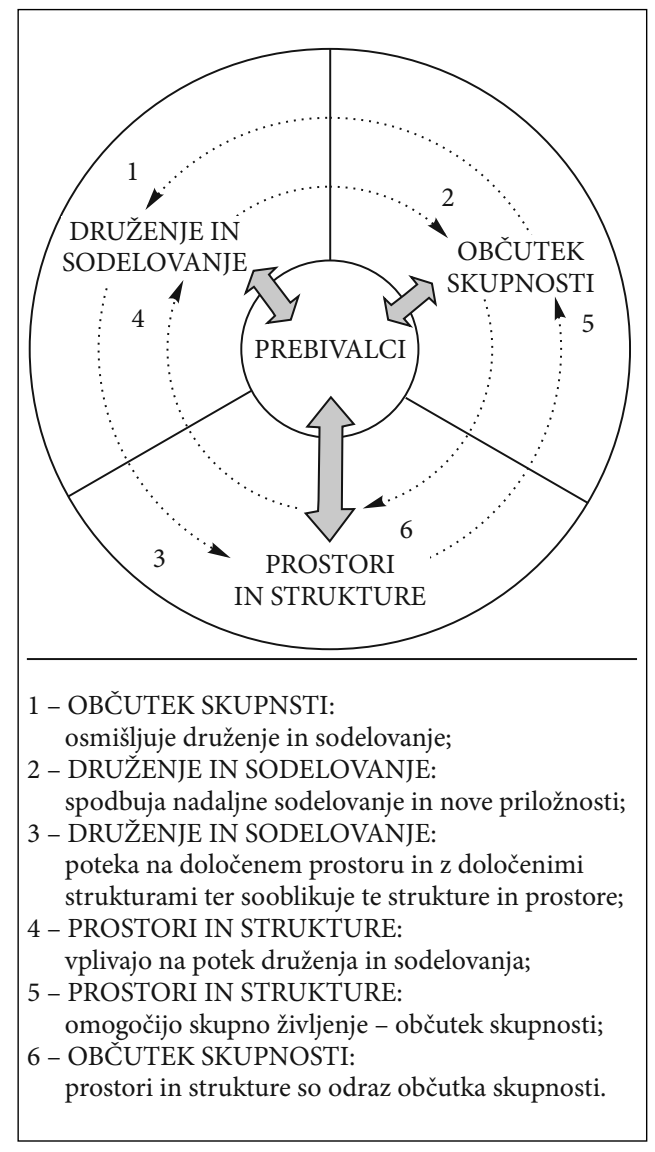


povezan s stabilnostjo, soodvisnostjo in varnostjo, hkrati pa ima tudi »temno stran «, saj so tesno povezane podeželske skupnosti tiste, ki ustvarjajo neenakosti in spodbujajo izključenost (Woods 2011, 163). Tako je Liepinsova (2000) na podlagi raziskav na Novi Zelandiji označila ljudi kot najpomembnejši sestavni del podeželske skupnosti (2000; slika 1). Vendar pa ljudje sami še ne naredijo skupnosti. Ljudi v podeželsko skupnost povezujejo trije elementi: medsebojno druženje in sodelovanje, skupni prostori in strukture ter občutek skupnosti.

Med temi elementi se izoblikuje medsebojna soodvisnost. Člani podeželske skupnosti vplivajo na spreminjanje ostalih elementov podeželske skupnosti (na skupne prostore, načine druženja in sodelovanja), hkrati se tudi člani podeželske skupnosti njim prilagajajo (na primer razpoložljivi skupni prostori vsaj deloma lahko vplivajo na način preživljanja prostega časa). Ta pristop dokazuje, da podeželske skupnosti niso statične in stabilne, kot so jih prikazovali zgodnji koncepti skupnosti, temveč so dinamične in tekmovalne skupine ljudi, oblikovane znotraj družbenega in političnega konteksta. Pomembno vezivo skupnosti je občutek pripadnosti, ki se v podeželskih skupnostih ob upoštevanju zgodovinskega spomina in udejanjanju sodobnih praks odraža na dva načina. Prvič je razviden v občutku pripadnosti skupnosti: ljudje delijo skupno identiteto, vključujejo se v enake prakse, drug drugega podpirajo, si medsebojno pomagajo, pripadajo skupnosti. Po drugi strani pa je pripadnost razvidna tudi iz občutka pripadnosti kraju: le-ta se odraža točkovno oziroma v materialnih prostorih znotraj območja skupnosti (na primer reka, most, šola, cerkev, dvorana, gostilna), kjer se skupnost prakticira.

Danska raziskovalca podeželja Svendsen in Sørensen (2007, 453-455) poudarjata vlogo proučevanja sprememb v podeželskih skupnostih z vidika druženja (bolj ali manj redno srečevanje ljudi) in sodelovanja (opravljanje določenih nalog ali opravil). S tem se zaznavajo tako procesi v prostoru kot tudi $\mathrm{z}$ njimi povezane spremembe norm, pravil in vrednot; oboje vpliva na povezanost $\mathrm{v}$ socialne strukture in mreže, s katerimi se dosega dobrobit za posameznika ali skupnost. Pri raziskovanju podeželske skupnosti se soočamo še s tretjo dilemo, in sicer, da se v našem primeru osredinjamo le na »prostorsko stabilne" podeželske skupnosti. Pri tem se zavedamo povečanega števila ter oblik mobilnih in prehodnih podeželskih skupnosti; njihova navezanost na določeno podeželsko lokaliteto je omejena (na primer lastniki sekundarnih bivališč, delavci migranti).

V raziskavi smo sledili izhodišču, da se vsaka podeželska skupnost kot enota absolutnega prostora (lokaliteta) spreminja pod vplivom številnih dejavnikov. Podeželska skupnost ima zato zapleteno zgradbo, ki jo medsebojno povezujejo (ne)snovni in kvantitativno težje merljivi viri, tokovi ter odnosi v pokrajini (Halfacree 2006; Potočnik Slavič 2010). Na spremembe podeželskih skupnosti lahko vplivajo nepredvideni in izjemi dogodki (na primer naravne nesreče), ki pa jih v našem prispevku ne analiziramo, ker se osredotočamo na družbenogospodarske dejavnike. S proučevanjem vloge migracij, skupnih prostorov druženja, možnosti izbire in ugotavljanjem stopnje funkcionalne, gospodarske ter socialne heterogenosti so prikazane razvojne smeri odnosov in tokov znotraj koncepta podeželske skupnosti.

\section{Metodologija}

\subsection{Metode raziskovanja}

Konceptualizacija podeželske skupnosti po Liepensovi (2000) predvideva kombinirane metode dela, ki omogočajo (relativno) celosten pogled na njen razvoj in delovanje (Cecchi 2003). V raziskavi smo upoštevali večino $\mathrm{v}$ relevantni literaturi predlaganih, dodali pa tudi nekatere druge metode dela.

Analiza znanstvenih, strokovnih in poljudnih besedil ter razprav (diskurzov), ki nakazujejo oblikovanje, razvoj in spreminjanje podeželske skupnosti. Interdisciplinarni pristop k raziskovanju podeželskih skupnosti je zahteval analizo literature (s področja geografije, sociologije, zgodovine, 
antropologije, politologije, ekonomije) različnih jezikovnih okolij (angleško, francosko, nemško in italijansko). Rezultati so pokazali velik manko primerjalnih študij na lokalni ravni, s katerimi bi lažje, bolj objektivno in preverljivo analizirali skupne lastnosti ter posamezne razlike med podeželskimi skupnostmi (Rigg 1994; Klemenčič 2010). Primerjalne študije so ključnega pomena pri proučevanju kvalitativnih in težje merljivih pojavov, kjer se raziskovalčeva objektivnost in nepristranskost sicer težko zagotavljata (Ferragina 2012).

Podroben in sistematičen pregled dogodkov, običajev in vsakodnevnih medsebojnih vplivov v podeželski skupnosti. $Z$ analizo zgodovinskih virov, s sodelovanjem lokalnega prebivalstva (Basaj 2014; Podjed 2014; Rebernik 2014) in poznavalcev razmer v podeželskih skupnostih (Potočnik Slavič 2013; Bröckling 2014; Grabski-Kieron 2014; Pletziger 2014) smo v raziskavo vključili društvene in zasebne arhive z letopisi, kronikami, zapisniki sej ter fotografsko gradivo. Vzpostavili smo stike s pristojnimi ustanovami, ki hranijo zgodovinske vire (na primer Gorenjski muzej, Zgodovinski arhiv Ljubljana Enota za Gorenjsko Kranj, Mestna knjižnica Kranj, časopis Landwirtschaftlichen Wochenblatt Westfalen-Lippe). Pregled dogodkov, običajev in vsakodnevnih medsebojnih vplivov je omogočil oblikovanje časovnega prereza spreminjanja podeželske skupnosti od agrarne preko industrijske do postindustrijske (informacijske) družbe.

Celovita analiza delovanja skupnosti s participativnim raziskovalnim pristopom. Za neposreden vpogled $\mathrm{v}$ današnje delovanje podeželske skupnosti in za prepoznavanje prevladujočih razvojnih procesov ter teženj, je bila uporabljena metoda poglobljenega polstrukturiranega intervjuja s terenskim delom, s katero se je najlažje ohranilo ravnovesje med vnaprej zastavljenimi raziskovalnimi cilji in prožnim zaznavanjem skupnih lastnosti, razvojnih procesov in teženj v podeželskih skupnostih. V raziskavi je bilo izvedenih 30 intervjujev, to je po pet intervjujev v šestih izbranih naseljih oziroma po 15 intervjujev v Sloveniji in Nemčiji (vsi intervjuji so bili opravljeni v letu 2014). Intervjuvani so bili prebivalci, ki so predstavljali različne socialne skupine v naselju: mladi, starejši, kmetje, predstavniki lokalne oblasti ter člani društev. Vsi intervjuji so posneti in transkribirani. Intervjuji z nemškimi intervjuvanci so bili ob transkripciji prevedeni v slovenski jezik. Bogato in obsežno gradivo (hrani se pri avtorjih prispevka) je bilo obdelano z metodo Atlas.ti, ki s pomočjo računalniškega orodja omogoča sistematično in strukturirano vsebinsko analizo in primerjavo odgovorov intervjuvancev. Verodostojnost nekaterih odgovorov, ki se nanašajo na konkretne dogodke in prireditve v podeželskih skupnostih, je bila preverjena tudi z zbranimi zgodovinskimi viri. V prispevek so vključeni tudi najbolj reprezentativni citati $\mathrm{z}$ nakazano identiteto intervjuvanca (spol, starost, kraj bivanja).

Terensko delo na izbranem območju s proučevanjem in kartiranjem prostorov in struktur podeželskih skupnosti. Terensko delo je vključevalo tudi fotografiranje in popis formalnih in neformalnih prostorov druženja v naselju in njihovi okolici (na primer cerkev, dvorane, pešpoti, športna igrišča, dogodki manjšega obsega). S pomočjo shematiziranih grafičnih prikazov, ki temeljijo na terenskih ugotovitvah z Gorenjske in Sauerlanda, so prikazani relevantni prostorsko-družbeno-časovno procesi spreminjanja proučevanih podeželskih skupnosti.

\subsection{Proučevane podeželske skupnosti}

Proučevane podeželske skupnosti so v dveh medsebojno precej različnih državah Evropske unije: tri naselja so v Republiki Sloveniji in tri v Zvezni republiki Nemčiji (območji proučevanja sta prikazani na sliki 2). Za izbor ustreznih podeželskih skupnosti so bili predhodno oblikovani štirje kriteriji, ki so omogočali izbiro podeželskih skupnosti na vitalnem podeželju in hkrati zagotavljali medsebojno primerljivost ter relevantnost rezultatov posameznih študij primerov. $Z$ medsebojno primerjavo se pojasnjuje učinkovanje raznovrstnih dejavnikov na podeželske skupnosti, hkrati pa se razkrivajo podobnosti in tudi razlike glede druženja ter sodelovanja v daljšem primerjalnem obdobju. Prikazane so spremembe odnosov in tokov znotraj proučevanih podeželskih skupnosti, ki jih povzroča družbenogospodarski razvoj. 


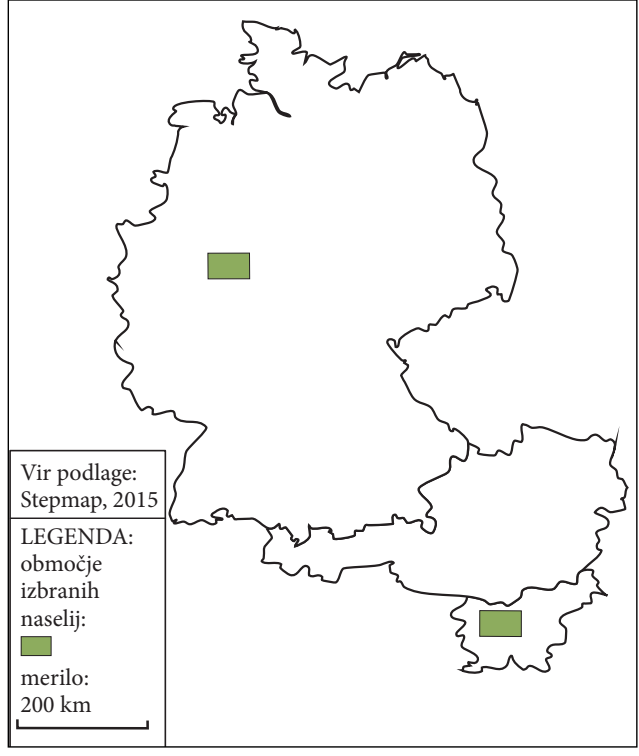

Slika 2: Geografska lega proučevanih podeželskih območij.

Obe proučevani območji (Gorenjska v Sloveniji in Sauerland v Nemčiji) sta demografsko stabilni: od konca druge svetovne vojne do leta 2015 se število prebivalcev v proučevanih naseljih ni zmanjšalo oziroma se je celo povečalo. Demografska stabilnost je eden temeljnih dejavnikov, ki zagotavljajo človeške vire in s tem omogočajo razvoj območja (Ceccato in Persson 2003). Odseljevanje ruši socialne strukture in slabi učinke druženja ter sodelovanja $v$ podeželski skupnosti in povzroča posebne razvojne probleme demografsko ogroženih območij (Svendsen 2006; Klemenčičc, Lampič in Potočnik Slavič 2008).

V vseh proučevanih naseljih prevladuje bivalna funkcija (sliki 3 in 4), naselja niso občinska središča, nimajo krajevnih uradov, trgovine z živili ( $\mathrm{z}$ izjemo Olševka), osnovne šole in vsakodnevne verske oskrbe. Večina prebivalcev vsakodnevno migrira zaradi zaposlitve in/ali šolanja ter oskrbe z živili, širše ponudbe storitev in občasno tudi zaradi pestrejših možnosti preživljanja prostega časa v občinska in regionalna središča (Kranj za slovenska naselja ter Meschede z manjšimi okoliškimi mesti za nemška naselja).

V proučevanih naseljih se vloga kmetijstva spreminja. Izbrana naselja so imela v svojem prostorskočasovnem razvoju podoben izhodiščni položaj. V agrarni razvojni stopnji je v vseh naseljih prevladovalo kmetijstvo, ki je pustilo sledove ne le v današnji fiziognomiji naselij (hlevi, skednji in kmečki vrtovi), temveč je zaznamovalo tudi identiteto, delovanje in medsebojno povezovanje tamkajšnjih skupnosti (Klemenčič 2003; Magnani in Struffi 2009). Zaradi industrializacije in družbenogospodarskega razvoja po drugi svetovni vojni se je število aktivnih kmetij zmanjšalo: v naselju Helmeringhausen danes ni več aktivnih kmetij, največ (15) aktivnih kmetij pa je na Suhi pri Predosljah. Proces deagrarizacije je povzročil predrugačenje socialnih struktur ter je s tem vplival tudi na značilnosti druženja in sodelovanja v podeželskih skupnostih.

V izbranih naseljih je sedež vsaj enega aktivnega društva. Aktivnosti in razvojne težnje društvenega življenja so kazalec vpetosti podeželskih skupnosti v prostorsko-časovne procese družbenogospodarskega razvoja: odsevajo spremembe v namenih in ciljih povezovanja prebivalcev v naselju. Društva morajo tako v slovenskem kot tudi nemškem pravnem redu voditi računovodsko dokumentacijo, kroniko delovanja oziroma letopis, ki za proučevanje podeželske skupnosti služijo kot eden temeljnih zgodovinskih virov (Zakon o društvih 2006; Vereingesetz 2007). 


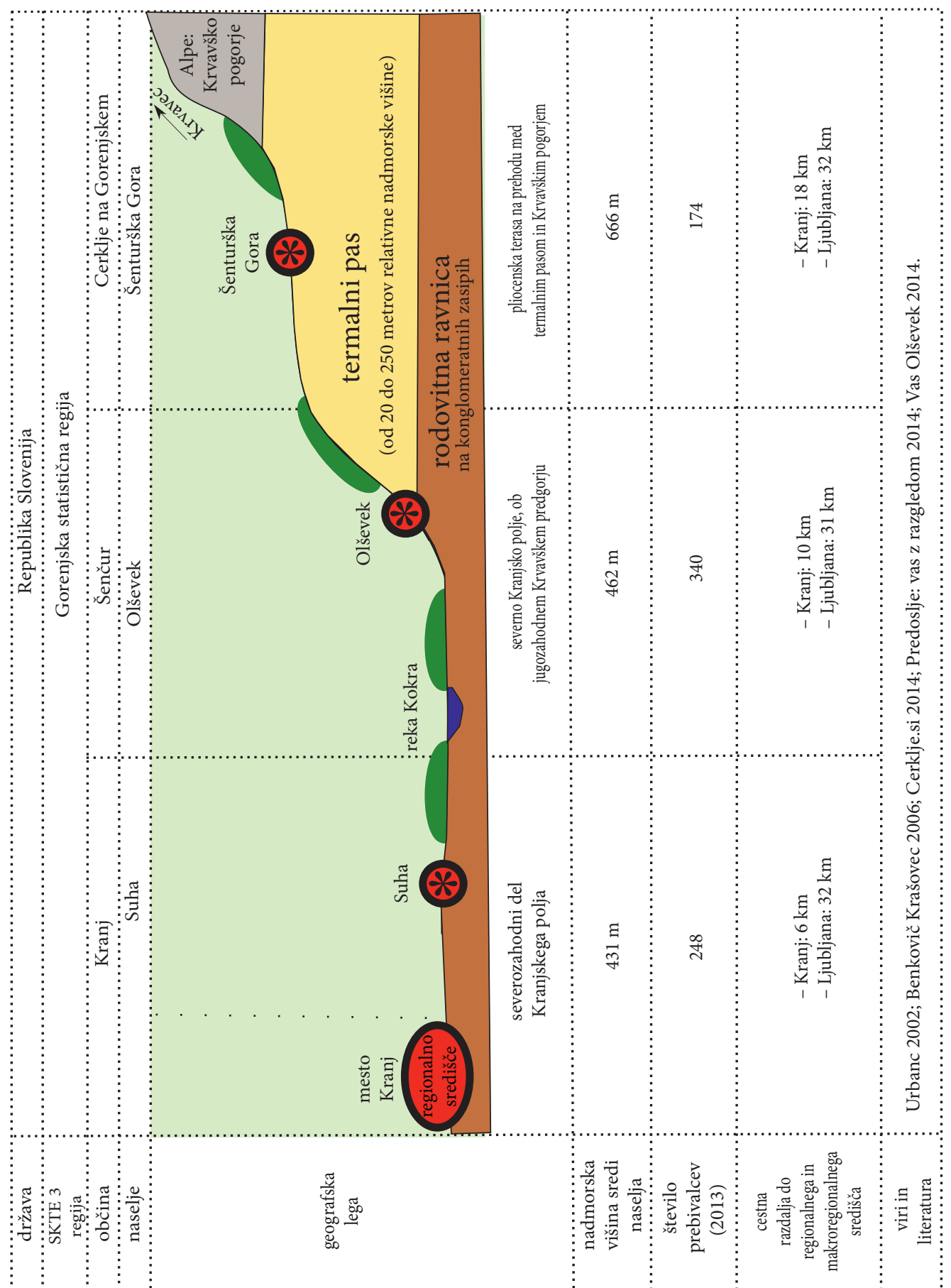

Slika 3: Prikaz geografskih značilnosti proučevanih naselij na Gorenjskem. 


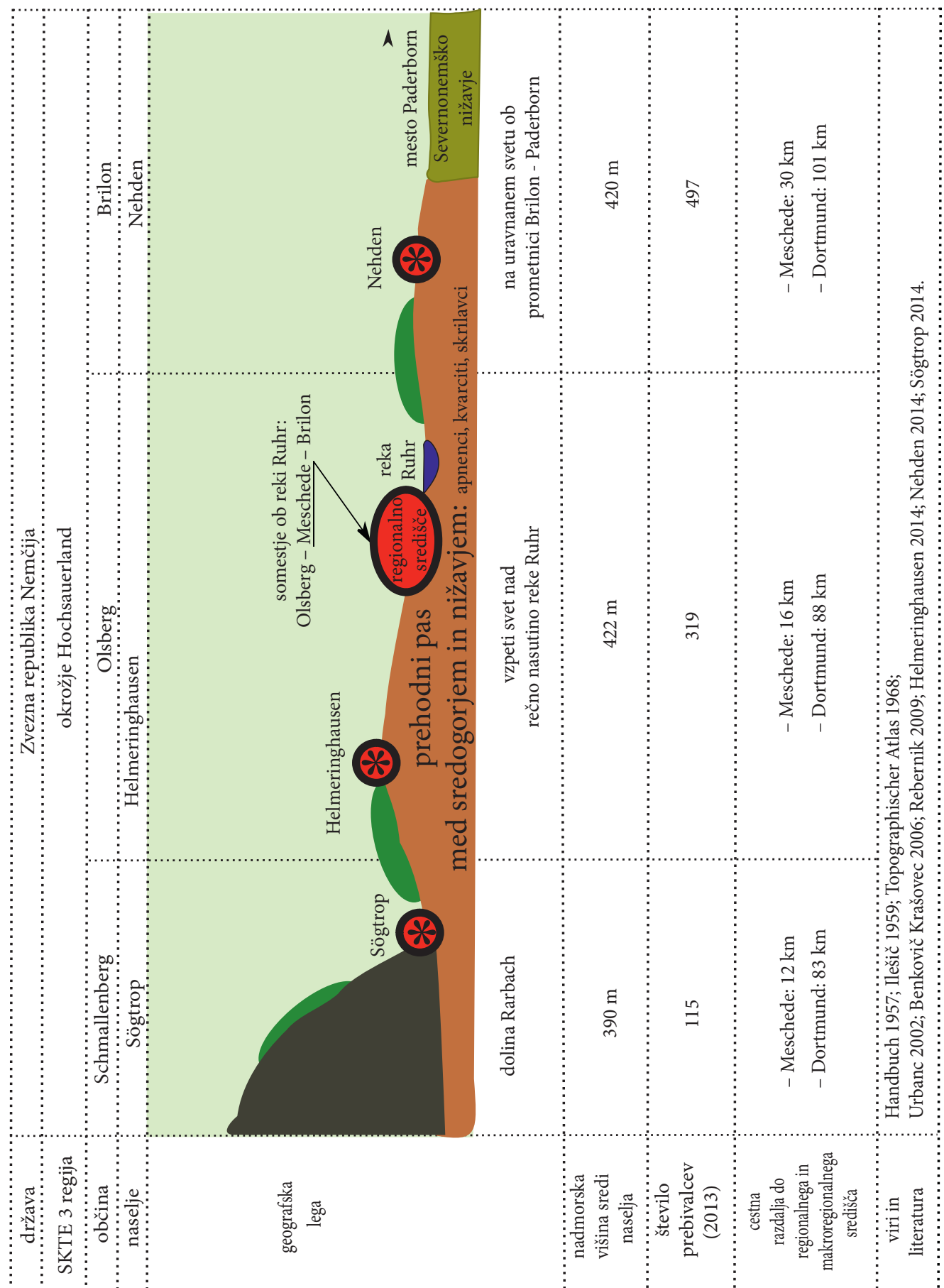

Slika 4: Prikaz geografskih značilnosti proučevanih naselij v Sauerlandu. 


\section{Rezultati in razprava}

Razvojne smeri odnosov in tokov $\mathrm{v}$ konceptu podeželske skupnosti so $\mathrm{v}$ raziskavi proučevane $\mathrm{z}$ vidika štirih različnih, vendar medsebojno tesno povezanih kazalcev. Z njimi so nakazani procesi spreminjanja podeželskih skupnosti ter hkrati prikazane tudi medsebojne razlike in posebnosti.

\subsection{Vpliv dnevnih migracij}

Prebivalci so v agrarni razvojni stopnji, to je do sredine 20. stoletja, le redko migrirali iz podeželskih skupnosti; izjema so bili otroci iz naselja Suha, ki so vsak dan hodili v sosednje Predoslje v šolo. V vseh ostalih naseljih se je podružnična šola obdržala do srede petdesetih let 20. stoletja, le na Olševku deluje tudi danes. Ostale migracije iz naselij so bile maloštevilne in prostorsko omejene. V okoliških mestih so prebivalci podeželske skupnosti včasih prodajali svoje pridelke (predvsem v Kranju za slovenska naselja in v mestih Meschede, Brilon in Olsberg za nemška naselja). Le redkokdo je bil v agrarni razvojni stopnji že zaposlen izven domačega naselja.

V agrarni razvojni stopnji sta bila v podeželski skupnosti življenje in vsakodnevno delo posameznika močno lokalizirana - vezana na naselje in njegovo funkcionalno območje (slika 5). Večino življenja so ljudje preživeli v podeželski skupnosti, saj je bila pretežno (prehransko in gospodarsko) samozadostna. Prebivalci so bili v svoj življenjski prostor, ki je bil omejen večinoma na podeželsko naselje in njegovo okolico, »vkoreninjeni«. Preživljanje prostega časa je bilo neločljivo povezano z delom, druženjem in medsebojnim sodelovanjem v podeželskem naselju. Življenje v in skupaj s podeželsko skupnostjo je bilo večini prebivalcev vnaprej določen način življenja, brez velikih možnosti za spremembe. Motivov za prostorsko (in tudi socialno) mobilnost zaradi gospodarske samozadostnosti skupnosti skorajda ni bilo.

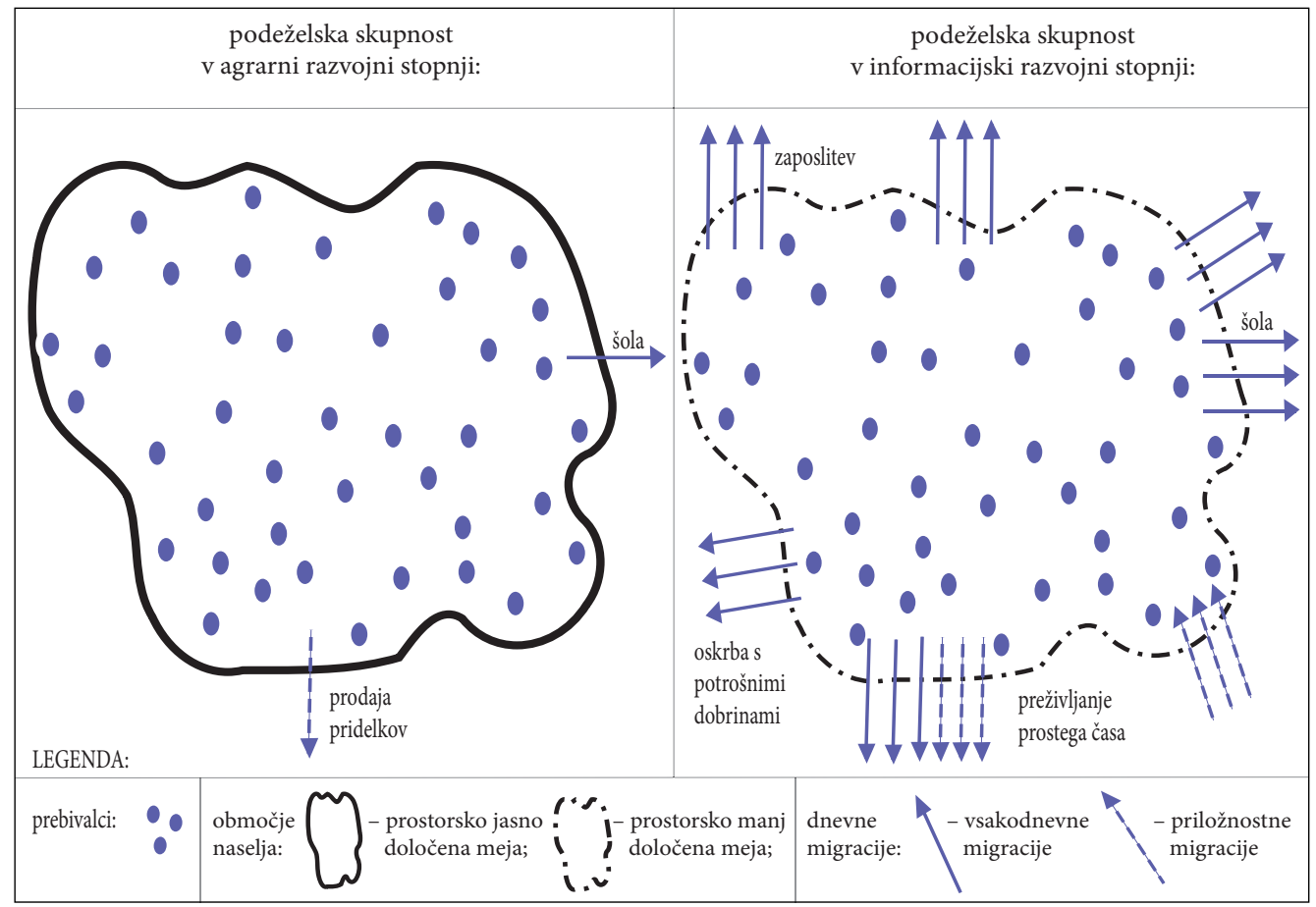

Slika 5: Vpliv dnevnih migracij na podeželsko skupnost $v$ agrarni in informacijski razvojni stopnji. 
V industrijski razvojni stopnji je vloga kmetijske dejavnosti pri druženju in sodelovanju v podeželski skupnosti postopno začela upadati. Vse manj prebivalcev je bilo neposredno odvisnih od kmetijstva, saj so se zaradi industrializacije v okoliških mestnih središčih pojavila nova delovna mesta in s tem pospešila povečevanje števila dnevnih migrantov iz podeželskih naselij v naselja višjih središčnih stopenj (Logar 2013; Razpotnik Visković in Seručnik 2013). Število kmetij se je zaradi zaposlovanja v drugih gospodarskih panogah močno zmanjšalo. Procesa deagrarizacije in industrializacije sta povzročila predrugačenje socialnih struktur in sta s tem vplivala tudi na značilnosti druženja in sodelovanja v podeželskih skupnostih, na primer pri medsebojni sosedski pomoči. Na tovrstne procese in spremembe v podeželski skupnosti kažeta tudi spodnja citata iz intervjujev tako slovenskih kot tudi nemških intervjuvancev:

»Medsosedske pomoči je med kmeti na Suhi /.../ vsako leto manj. Danes nihče več nima časa za pomoč, nekdo ima službo, nekdo delo doma, tretji pa že najde kakšen izgovor. Tudi košnja trave, ki je bila nekdaj podvig cele vasi, je danes povsem obvladlivia, saj imamo vsi sodobno mehanizacijo in se pomoči drugih skoraj ne potrebuje.»

(Suha, ženska, 41 let)
"Po vojni se je veliko spremenilo, $v$ vasi je bilo vse manj kmetov, čeprav je prej skoraj vsaka od takrat 20 hiš imela vsaj kokoši, svinjo in kravo. Življenje je bilo poceni. Kdor je imel pred vojno eno ali dve kravi, se mu ni več splačalo, saj je dobil službo v mestu.«

(Sögtrop, moški, 84 let)

V informacijski razvojni stopnji so vsem podeželskim skupnostim skupne dnevne migracije iz naselij in »odvisnost « od osebnih prevoznih sredstev. Z družbenogospodarskim razvojem (gospodarskih dejavnosti, prevoznih sredstev, deagrarizacije, krepitve komuniciranja in trgovanja na globalni ravni) so prebivalci vse manj odvisni od življenja v podeželski skupnosti. Pojavile so se nove priložnosti za delo, preživljanje prostega časa in možnosti oskrbe s hrano izven podeželskega naselja, običajno v naseljih z več središčnimi dejavnostmi. Podeželska skupnost je zaradi močno zmanjšane vloge kmetijske dejavnosti na življenje posameznikov vse manj odvisna od funkcionalnega območja okoli naselja (Guštin in Potočnik Slavič 2015). Življenjski prostor prebivalcev se širi in se nič več ne omejuje samo na kraj bivanja (Benkovič Krašovec 2006). Življenje zaznamuje vse višja stopnja dnevne prostorske mobilnosti, s tem pa podeželska skupnost postaja »raztočna«: ne le zaposleni, temveč tudi mladi in upokojeni večino svojega dneva lahko preživijo izven podeželske skupnosti. Na veliko vlogo lastnih prevoznih sredstev in dnevnih migracij so opozorili tudi intervjuvanci iz obeh proučevanih podeželskih območij:

"Danes mora imeti vsak svoj avtomobil, da se lahko zapelje do službe v Kranju."

(Šenturška Gora, moški, 50 let)
"Ljudje se vsak dan vozijo $v$ mesto Meschede, saj jih je tam večina zaposlenih.«

(Sögtrop, ženska, 70 let)

Kljub temu se v informacijski razvojni stopnji ne sme podcenjevati vloge podeželske skupnosti; skupno preživljanje prostega časa (p)ostaja pomemben vidik druženja in sodelovanja v podeželski skupnosti ne le za domačine, temveč tudi za druge prebivalce (prim. okoliških naselij, bližnjih mest), ki jim je tak način preživljanja prostega časa všeč. Na sliki 5 zato puščice, ki predstavljajo dnevne migracije prebivalcev, ne vodijo zgolj iz podeželske skupnosti, temveč (vsaj pri preživljanju prostega časa) vodijo tudi nazaj v podeželsko skupnost.

\subsection{Možnost izbire $v$ informacijski razvojni stopnji: živeti v podeželskem naselju ni enako kot živeti v podeželski skupnosti}

Podeželske skupnosti so bile v agrarni razvojni stopnji prostorsko relativno zaokrožene delovne enote na funkcionalnem območju svojih naselij, znotraj katerih je potekala koordinacija in opravljanje (kmetijskih) opravil. Prebivalce v podeželskem naselju ni povezalo zgolj skupno delo, temveč tudi prosti čas 
in medsebojna pomoč v okviru podeželske skupnosti. Živeti v podeželski skupnosti je pomenilo enako kot živeti v podeželskem naselju; kdor je živel v naselju, je bil običajno tudi del tam živeče skupnosti. Socialni odnosi v podeželski skupnosti so bili prostorsko zgoščeni na območju podeželskega naselja in so tvorili prostorsko relativno gosto socialno mrežo (slika 6). Socialna mreža je nekakšno prostorsko tkivo oziroma struktura podeželske skupnosti, ki ni osnova zgolj medsebojnemu druženju in sodelovanju v podeželski skupnosti, temveč omogoča tudi razvoj občutka skupnosti oziroma identitete. Na vse šibkejši občutek skupnosti oziroma vse manjšo povezanost med prebivalci podeželske skupnosti kažeta tudi sledeča citata intervjuvancev z obeh proučevanih območij:

»V̌́asih je bilo medsebojno sodelovanje mnogo pomembnejše, saj je bila večina dela ročna: si predstavljaš, koliko časa bi ena ženska sama žela celo njivo p̌̌enice s srpom in koliko časa bi ena družina sama mlatila žito? Danes pa je mehanizacija tako močna, da se ljudi skoraj ne potrebuje več /.../."

(Suha, moški, 45 let)
"Ljudje smo bili bolj povezani v vsakdanjem življenju kot danes. Kdor je imel vsaj eno kravo, si je pri sosedu sposodil mleko, ko je bila breja; ko je bila sosedova krava breja, ga je dal nazaj. Sosedu si šel pomagat, če je bila krava bolna ali če je dobila telička. Ta povezanost danes manjka, to pogrešam v vasi.«

(Sögtrop, moški, 84 let)

Socialna mreža podeželske skupnosti je v informacijski razvojni stopnji med nekaterimi prebivalci večkrat »raztrgana « in manj celovito povezuje prebivalce kot v agrarni razvoji stopnji, saj so med njimi zgolj bežna poznanstva oziroma se prebivalci med seboj sploh ne poznajo (slika 6). Te spremembe v podeželski skupnosti nastajajo zaradi razvoja sodobnih prevoznih sredstev ter telekomunikacijskih omrežij; vloga prostorskih razdalj pri komunikaciji in sodelovanju se med prebivalci močno spreminja.

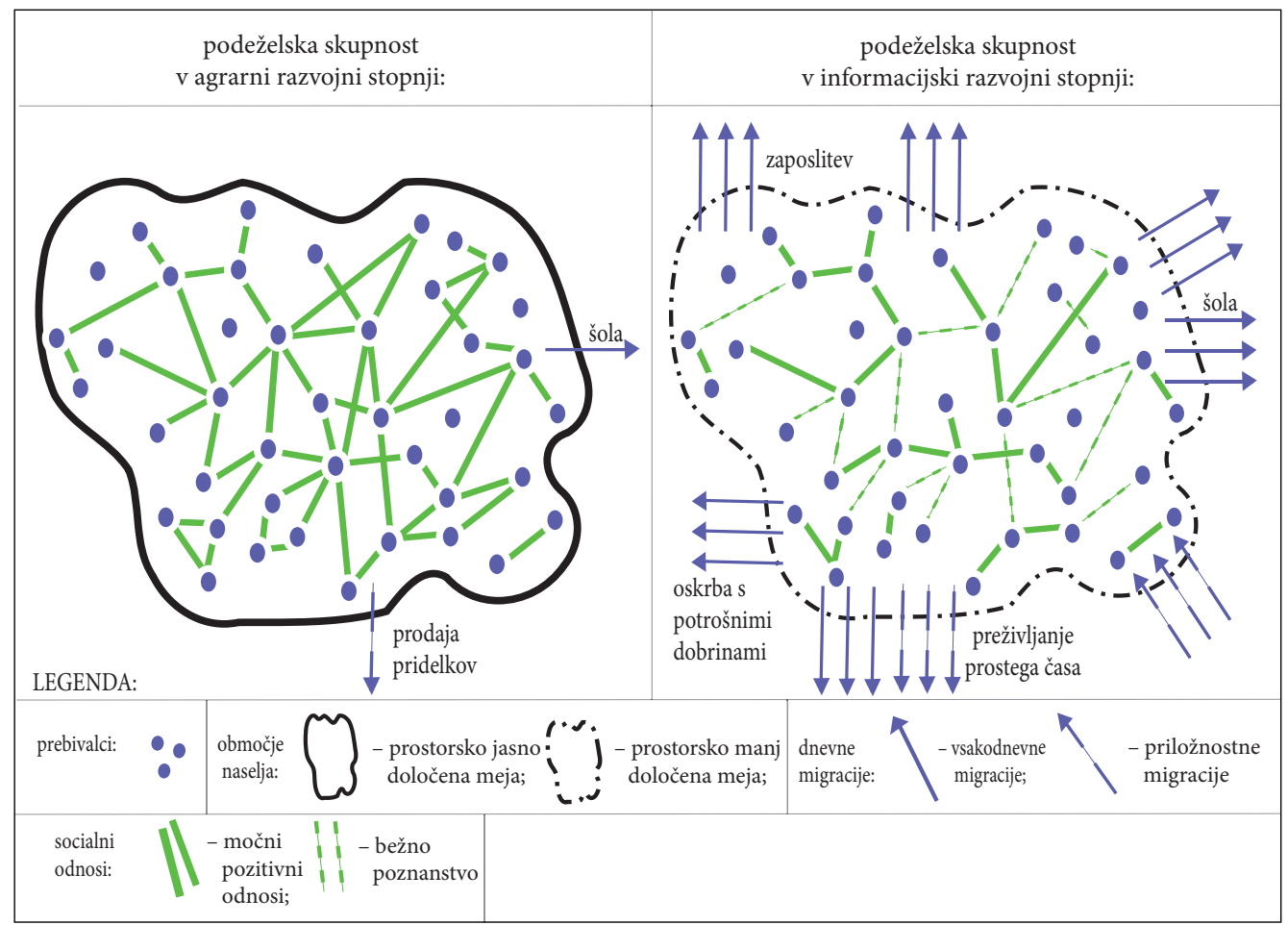

Slika 6: Socialni odnosi v podeželski skupnosti v agrarni in informacijski razvojni stopnji. 
Medosebne vezi in informacijski tokovi vse pogosteje potekajo po virtualnem omrežju (Mlinar 2012; Rutten, Westlund in Boekema 2010). Prebivalci so zato mnogo bolj »izkoreninjeni« iz podeželske skupnosti oziroma so vanjo manj vpeti kot na začetku proučevanega obdobja. Za druženje in sodelovanje v njej se ljudje nenehno zavestno odločajo oziroma izbirajo med različnimi možnostmi in ponudbami v številnih bolj ali manj oddaljenih naseljih.

Življenje v podeželski skupnosti je pod vplivom sprememb tako družbenogospodarske podobe življenja posameznika kot celotne družbe postal le ena od možnih izbir načina življenja na podeželju. Te spremembe so močno predrugačile tudi uveljavljene tradicionalne oblike druženja in sodelovanja v podeželski skupnosti; živeti v podeželski skupnosti ne pomeni več enako kot živeti v podeželskem naselju. Življenje $\mathrm{v}$ podeželski skupnosti je $\mathrm{v}$ informacijski razvojni stopnji postalo le en izmed številnih (alternativnih) načinov življenja, ki si ga prebivalec v podeželskem naselju lahko izbere in deloma tudi sam po svoji predstavi o podeželju uredi (Potočnik Slavič 2010). Proučevane podeželske skupnosti postajajo zaznamovane $\mathrm{z}$ raznorodnostjo (heterogenostjo) in oddaljenostjo od tradicionalnega pojmovanja podeželskih območij (Klemenčič 2006).

\subsection{Spremenjena vloga skupnih prostorov podeželske skupnosti}

V proučevanih podeželskih skupnostih imajo skupni prostori v naselju in njegovi funkcionalni okolici (na primer cerkve, verska znamenja, spomeniki, gasilski in krajevni domovi) za prebivalce posebno vlogo (slika 7). Na skupne prostore so ponosni, saj jim omogočajo identifikacijo s kulturo v prostoru, v katerem živijo, in mu obenem dajejo pečat tam živeče podeželske skupnosti (Hazler 2010). Nekateri prostori (območja) v naseljih ali njihovi okolici so informacijska središča oziroma živčni centri podeželske

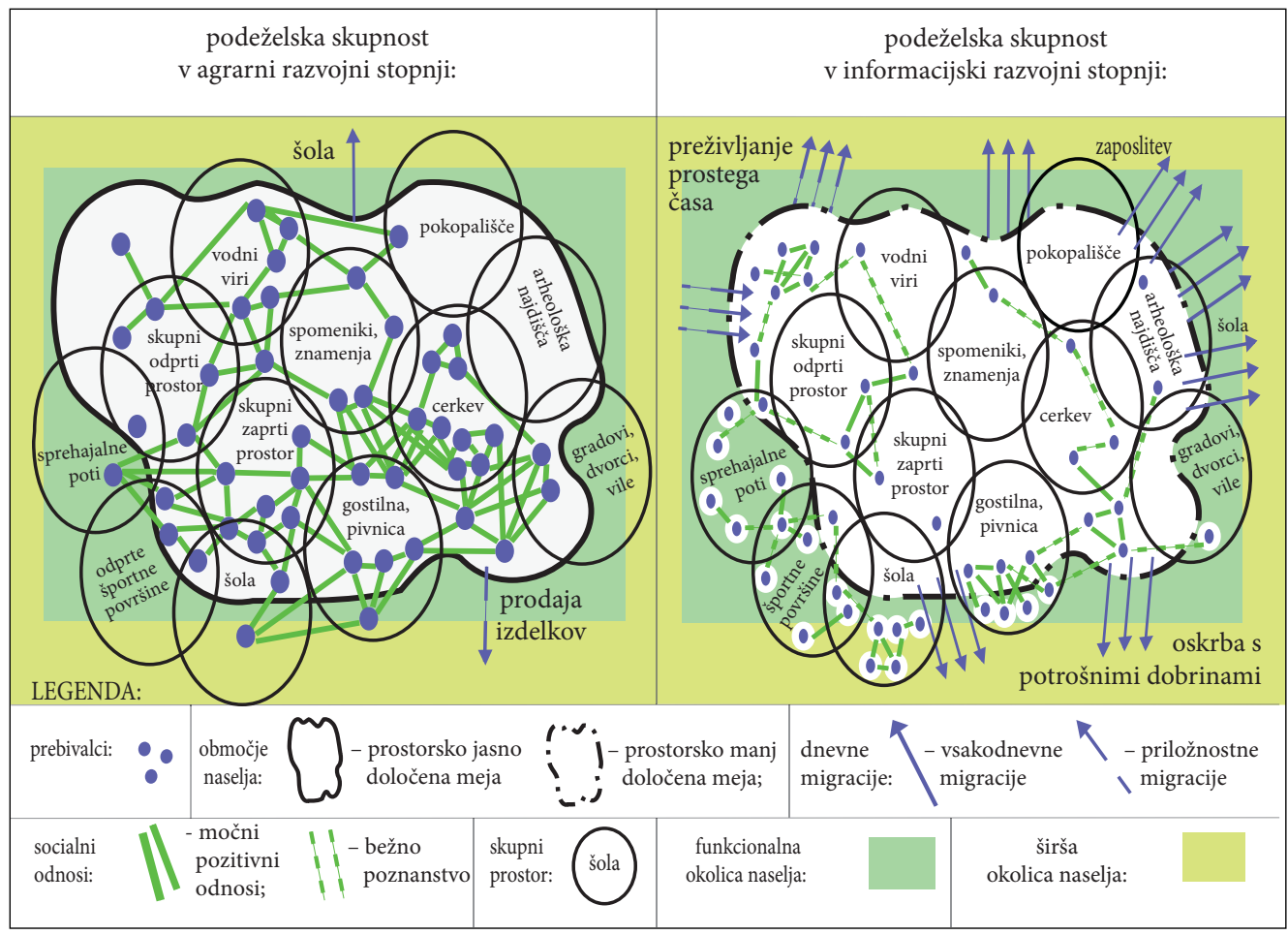

Slika 7: Vloga skupnih prostorov v podeželski skupnosti. 
skupnosti (Klemenčič 1995); tam so stekališča nevidnih tokov raznolikih idej in pobud, na primer v središču naselij, ob spomenikih, vodnih izvirih in zajetjih (Škrjanc 1999), v okolici naselij na poljskih in sprehajalnih poteh. Skrb za skupne objekte in območja v naselju je eden izmed skupnih ciljev, s katerimi se medsebojno sodelovanje v podeželski skupnosti ohranja ne glede na prostorsko-časovne spremembe (Zavrl Žlebir 1996).

Skupni objekti in nekateri deli funkcionalnega območja naselja so bili v agrarni razvojni stopnji glavna prizorišča, prostorska stičišča ter težišča druženja in sodelovanja podeželske skupnosti. Danes so nekateri skupni objekti in območja deloma neizkoriščeni ali celo v »funkcijskem vakuumu «, kot so stavbe nekdanjih podružničnih šol ali osrednji skupni prostori. Spremenjena (ne)raba objektov kaže na spremembe v načinu življenja v podeželskih skupnostih. Prebivalci so v informacijski razvojni stopnji bolj povezani s sprehajalnimi potmi, zaradi možnosti dnevne prostorske mobilnosti pa lahko tudi s številnimi objekti izven svojega naselja. Zaradi povečane mobilnosti, večje ponudbe storitev in s tem individualne izbire se aktivni domet podeželske skupnosti vse bolj širi tudi na primeru prostorov osebnega (in ne le virtualnega) srečevanja.

\subsection{Krepitev funkcionalne, gospodarske in socialne heterogenosti v podeželskih skupnostih spreminja uveljavljene načine druženja in sodelovanja}

V agrarni razvojni stopnji je bila podeželska skupnost gospodarsko in socialno relativno homogena $\mathrm{z}$ močno prevladujočo kmetijsko dejavnostjo. Druženje in sodelovanje v podeželski skupnosti sta bila povezana s kmetijskimi opravili na njihovem funkcionalnem območju. Na tak način je večina medsebojnih povezav prispevala k ohranjanju tako podobe naselja kot tudi njegovega funkcionalnega

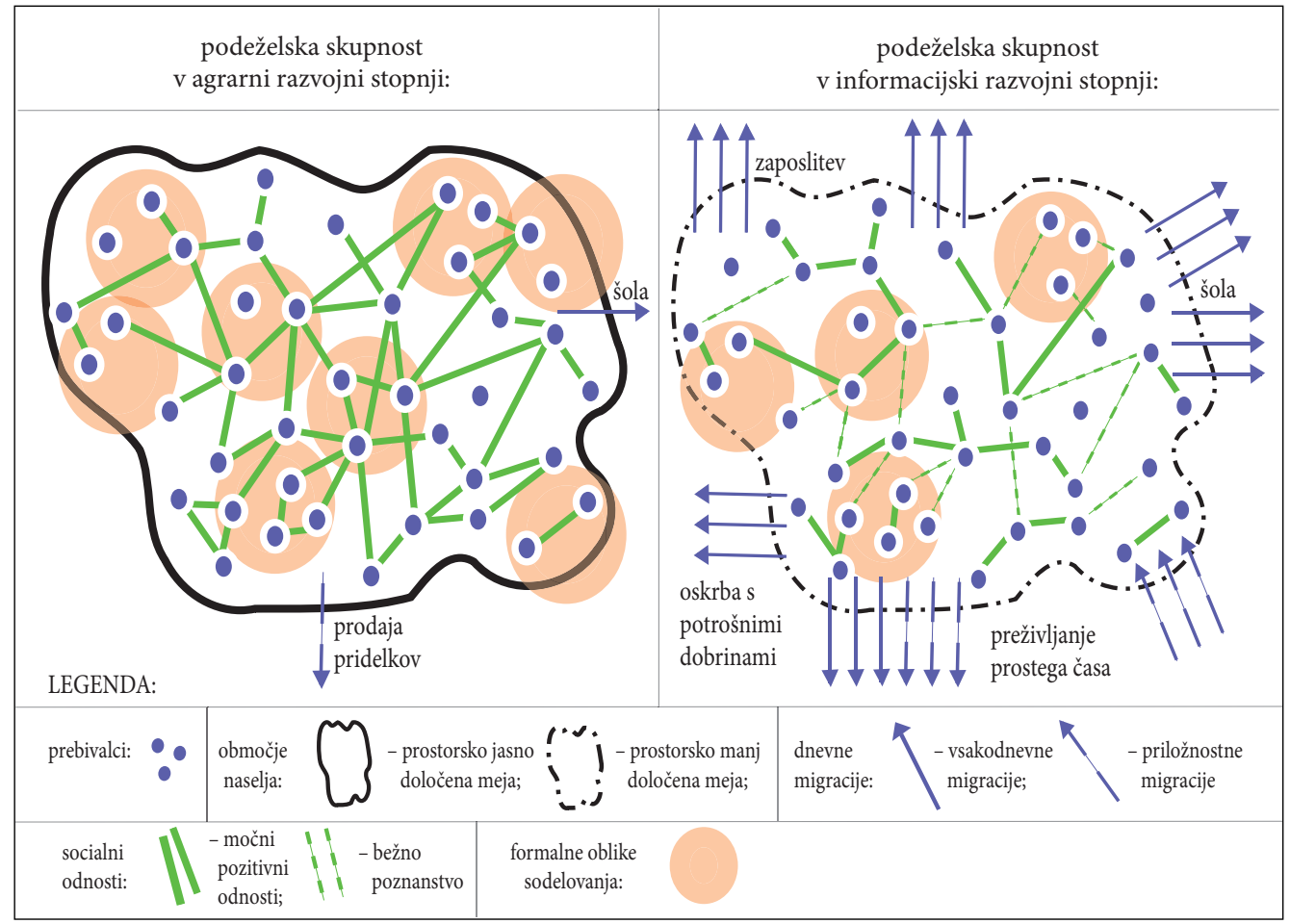

Slika 8: Vloga formalnih oblik druženja in sodelovanja v podeželski skupnosti. 
območja; s popravilom in gradnjo objektov, obdelavo kmetijskih zemljišč, urejanjem vodotokov, nasutjem cest in podobno. Povezava med posamezno podeželsko skupnostjo in njenim življenjskim okoljem je bila vidna v prostorski neprekinjenosti (Mlinar 2012), saj so bili simboli ter načini druženja in sodelovanja prebivalcev $\mathrm{v}$ podeželskih skupnostih avtentični in $\mathrm{v}$ tesni povezavi s (bližnjim) okoljem (Woods 2011). Tesna povezanost podeželskih skupnosti z njihovimi življenjskimi okolji se je odražala:

- v zunanji (materialni) podobi njihovih naselij: uporabljali so lokalne gradbene materiale, gospodarski objekti so bili v uporabi za kmetijsko dejavnost in/ali domače obrti;

- v nematerialnih (nesnovnih) značilnostih skupnosti: življenje v vaški skupnosti je bilo prepleteno s tesnimi medsebojnimi povezavami iz objektivnih in subjektivnih razlogov (Kladnik 1999), vpeti so bili v prehransko samooskrbo, tradicionalni življenjski stil in način delitve dela (Golob 1967; Kneževič Hočevar in Černič Istenič 2010).

Družbenogospodarski razvoj vse bolj pospešuje pretočnost blaga, storitev in informacij ter »koncentrirane dekoncentracije « dejavnosti (Mlinar 2012; Rutten, Westlund in Boekema 2010). Ti procesi brišejo tradicionalne simbole in načine življenja, ki so proučevanim podeželskim skupnostim v pokrajini utemeljevale njihovo identiteto in vrednote (Halfacree 2006). Značaj in delovanje proučevanih podeželskih skupnosti postajata vse manj povezana z značilnostmi funkcionalnega območja naselij. Pojem podeželskosti postaja deteritorializiran, saj podeželske skupnosti zaradi krepitve procesov deagrarizacije, globalizacije, digitalizacije in velike mobilnosti ljudi vse bolj izgubljajo stik s svojim življenjskim okoljem: njihovi pomenski znaki, simboli ter načini druženja in sodelovanja postajajo vse bolj pestri in odtujeni (neavtentični) od pripadajočih geografskih prostorov (Klemenčič 2006).

Čeprav podeželske skupnosti postajajo vse bolj zaznamovane z raznovrstnostjo (Halfacree 2006), so hkrati tudi ohranjevalke različnih načinov življenja. V njih ni mogoče razločiti med tradicionalnimi ter novimi elementi druženja in sodelovanja, saj skupaj sobivajo v medsebojni prepletenosti - imajo mozaično strukturo (Klemenčič 2003). Uveljavljene formalne oblike druženja in sodelovanja v podeželski skupnosti (društva, oblike verskega življenja, lokalna samouprava) nimajo več tako močne vloge pri povezovanju ljudi kot $\mathrm{v}$ agrarni in deloma tudi industrijski razvojni stopnji. Njihova vloga se spreminja zaradi vse bolj raznolikih delovnih mest in dejavnosti za preživljanje prostega časa ter možnosti oskrbe z materialnimi dobrinami zunaj podeželskega naselja (slika 8). V agrarni razvojni stopnji je bilo več medosebnih stikov znotraj formalnih povezav v podeželski skupnosti. V informacijski razvojni stopnji je število formalnih povezav med ljudmi praviloma nižje, saj uveljavljene oblike formalnega povezovanja v podeželski skupnosti zaradi večje možnosti izbire $v$ naseljih višjih središčnih stopenj praviloma ne pritegnejo več ljudi kot v prejšnjih razvojnih stopnjah.

\section{Sklep}

Družbenogospodarski razvoj odločilno vpliva na zgradbo in spremembe v vseh proučevanih podeželskih skupnostih: modernizacija življenja in dela na podeželju, raznolike prostorske migracije, možnost izbire življenjskega stila, pretočnosti in mnogoterosti povzročajo odmik prebivalcev od uveljavljenih struktur ter tradicionalnih oblik druženja in sodelovanja (Woods 2005). Podeželske skupnosti v informacijski dobi doživljajo raznovrstne pritiske, ki se zrcalijo v vidnih in nevidnih spremembah znotraj skupnosti. Geografi najpogosteje spremljamo vidne spremembe materialnega prostora (na primer modernizacija stavbnega fonda, vzpostavljanje novih gospodarskih dejavnosti, migracijski tokovi). Miselne predstave podeželanov o vsakdanjem življenju na podeželju spadajo med težje vidne in redkeje z geografskega vidika proučevane spremembe podeželske skupnosti (na primer odnos prebivalcev do novosti v naselju, dojemanje podeželske identitete). Uradne predstave o podeželju, ki jih sooblikujejo geografske in druge študije podeželja (členitve podeželja, programi razvoja podeželja ipd.), pomembno vplivajo na življenje podeželanov in na materialni prostor podeželja. 
Povezave med spremembami materialnega prostora ter miselnimi in uradnimi predstavami podeželja je smiselno proučevati primerjalno znotraj konkretnih podeželskih skupnosti. Medsebojno druženje in sodelovanje prebivalcev je vezivni socialni kapital podeželske skupnosti, ki se odraža v njeni notranji čvrstosti (Klemenčič 1995). V proučevanih podeželskih skupnostih na Gorenjskem in v Sauerlandu je bilo mogoče evidentirati znake (Halfacree 2006):

- skladnosti in združenosti: vidne in nevidne spremembe podeželske skupnosti se skladajo na sorazmerno mehak, a trden način (prim. želja po druženju in sodelovanju v vseh proučevanih podeželskih skupnostih kljub dnevnim migracijam in zaposlitvam zunaj domačega naselja med prebivalci ostaja, jih povezuje in navdaja $\mathrm{z}$ občutkom varnosti);

- protislovnosti in razkosanosti: vidne in nevidne spremembe nakazujejo raznovrstne napetosti znotraj podeželskih skupnosti, kar se pogosto odraža v različnih prostorskih praksah (prim. medsebojno nasprotujoča si mnenja o upravljanju s skupnimi prostori in društvi v podeželski skupnosti);

- kaotičnosti in nepovezanosti: podeželje in podeželske skupnosti obvladuje individualizirano vsakodnevno življenje, pogosto nepovezano na ravni dojemanja in predstav; vidne in nevidne spremembe odsevajo pomanjkanje lokalne notranje skladnosti, kar predstavlja potencialno razdiralne razvojne alternative in lahko v absolutni enoti prostora razbije podeželsko skupnost kot družbeni in simbolni konstrukt (prim. večina intervjuvancev poudarja, da je druženje in sodelovanje v podeželski skupnosti za prebivalce le ena od možnih izbir, za katero se lahko odločijo ali pa tudi ne).

Zaradi družbenogospodarskega razvoja ni več mogoče območja naselij enačiti z območjem podeželske skupnosti. Območja proučevanih podeželskih skupnosti postajajo gibljivi in dinamični prostori z močno prepletenimi medsebojnimi odnosi ter mrežno strukturo, vpeto tudi v širšo lokalno in regionalno raven. Podeželske skupnosti niso več podobne vase zaprtim, samozadostnim in izoliranim zabojnikom, temveč postajajo zbiralniki medsebojno raznolikih načinov življenja in družbenih praks (Halfacree 2006). Nič več niso kot samotni otoki v prostoru, temveč postajajo križišče oziroma stičišče različnih tokov v prostorsko-časovni razsežnosti (Mlinar 2012). Podeželje ni več »prostor krajev«, temveč »prostor tokov«.

Primerjava podeželskih skupnosti iz obeh držav ni pokazala zgolj enakih ali vsaj zelo podobnih učinkov družbenogospodarskega razvoja. Razkrite so številne posebnosti posameznih podeželskih skupnosti $\mathrm{v}$ uveljavljenih oblikah druženja in sodelovanja (na primer vodilna vloga gasilskih društev v Sloveniji in strelskih društev v Nemčiji). Analiza zgodovinskih virov in odgovori intervjuvancev kažejo, da je bilo življenje prebivalcev v proučevanih podeželskih skupnostih v agrarni razvojni stopnji - ob upoštevanju lokalnih družbenogospodarskih in kulturnih razmer - dokaj podobno. Prebivalci podeželske skupnosti so bili medsebojno povezani ne le zaradi želje po skupnem preživljanju prostega časa, temveč (predvsem) zaradi gospodarskega sodelovanja. Vsebinsko mnogo bolj so raznoliki odgovori intervjuvancev ob opisovanju sodobne vloge podeželske skupnosti ter pogledov/želja za njen nadaljnji razvoj. Pri tem ne gre spregledati, da se želja prebivalcev po druženju in sodelovanju v podeželski skupnosti ohranja, le da se motivi spreminjajo in vsebinsko postajajo vse bolj pestri ter se ponekod oddaljujejo od uveljavljenih oblik, kar je za podeželsko skupnost in tudi načrtovalce razvojnih politik velik izziv. Za krepitev in razvoj podeželskih skupnosti ni dovolj le razumevanje ključnih razvojnih procesov, v katere so vpete podeželske skupnosti. Upoštevati se mora tudi njihove posebnosti (tradicija, izročilo, običaji, novosti) ter mnenja in želje tamkajšnjih prebivalcev, saj podeželska skupnost le na tak način lahko aktivno sodeluje in uresničuje cilje in usmeritve koncepta neoendogenega razvoja. Preživetje podeželske skupnosti je odvisno od njihove prožnosti oziroma zmožnosti, da se soočijo s spremembami in se kreativno prilagodijo novim razmeram.

Spremembe v proučevanih slovenskih podeželskih skupnostih je smiselno proučevati in vrednotiti tudi z vidika vloge polkmetov, saj se je njihova večfunkcijska vloga (na primer kmetijska proizvodnja, ohranjanje kulturne pokrajine, uporabniki raznovrstnih storitev na podeželju) v podeželski skupnosti izoblikovala s povezovanjem redne zaposlitve (pogosto izven kraja bivanja), lastništva zemlje, bolj ali manj aktivne ter tržno usmerjene kmetijske dejavnosti, vključevanja v zadrugo, v ukrepe skupne kmetijske politike in njihovega medsebojnega povezovanja (Razpotnik Visković in Seručnik 2013). Z nji- 
hovo notranjo diferenciacijo (Logar 2013) na polkmete-podjetnike, samooskrbno-tržne polkmete in ostarele polkmete, se je pogosto oblikovalo več razvojnih jeder, iz katerih prihajajo raznovrstne pobude za druženje in sodelovanje v podeželskih skupnostih, ki so in/ali niso usklajene.

Zahvala: Raziskavo je finančno podprl program Erasmus+, skaterim je bilo mogoče razširiti proučevanje podeželskih skupnosti $v$ Nemčiji. Hvala za sodelovanje vsem intervjuvancem in predstavnikom proučevanih podeželskih skupnosti. Za pomoč in nasvete pri raziskovanju v Nemčiji gre posebna zahvala dr. Ulrike Grabski-Kieron $z$ Inštituta za geografijo na Univerzi v Münstru ter vodji LEADER projektov $v$ okrožju Hochsauerland, gospodu Stefanu Pletzigerju.

\section{Viri in literatura}

Basaj, I. J. 2014: O življenju na Suhi pri Predosljah po koncu druge svetovne vojne (osebni vir, 24.4. 2014). Predoslje.

Benkovič Krašovec, M. 2006: Centralna naselja na podeželju v Sloveniji. Geografski obzornik 53-3. Bröckling, F. 2014: O načinu izbire naselij v pokrajini Sauerland (osebni vir, 10. 10.2014). Münster.

Ceccato, V., Persson, L. O. 2003: Differential Economic Performance (DEP) in the periphery - Evidence from Swedish rural areas. European Journal of Spatial Development 7.

Cecchi, C. 2003: Public goods and public services - the process of building social capital in rural areas. Sidea, Gruppo di lavoro: Processi e politiche di sviluppo rurale. DOI: http://dx.doi.org/10.2139/ssrn.941196 Cerklje.si, 2014. Medmrežje: http://www.cerklje.si/ (29.12.2014).

Ferragina, E. 2012: Social Capital in Europe - A Comparative Regional Analysis. Northampton. DOI: http://dx.doi.org/10.4337/9781781000229.00007

Golob, M. 1967: Kooperativni odnosi na vasi v preteklosti in danes. Raziskovalno poročilo, RSS. Ljubljana. Grabski-Kieron, U. 2014: Izbor ustreznih naselij v zvezni deželi Severno Porenje-Vestfalija (osebni vir, 7. 10. 2014). Münster.

Guštin, Š. 2014: Določanje meje med mestom in podeželjem s pomočjo spoznavnih zemljevidov (na primeru občine Izola). Dela 41. DOI: http://dx.doi.org/10.4312/dela.41.7.129-144

Guštin, Š., Potočnik Slavič, I. 2015: Prepoznavanje in prostorska razmestitev konfliktov na podeželju. Geografski vestnik 87-1. DOI: http://dx.doi.org/10.3986/GV87105

Guštin, Š. 2016: Interaktivni scenariji rabe tal na podeželju občine Izola. Dokument je v izdelavi.

Halfacree, K. 1993: Locality and social representation: Space, discourse and alternative definitions of the rural. Journal of Rural Studies 9-1.

Halfacree, K. 2006: Rural space - constructing a three-fold architecture. Handbook of Rural Studies. London. DOI: http://dx.doi.org/10.4135/9781848608016.n4

Handbuch der naturräumlichen Gliederung Deutschlands. Veröffentlichungen der Bundesanstalt für Landeskunde. Bonn, 1957.

Hazler, V. 2010: (Raz-)vrednotenje dediščine? Globalizacija in utrjevanje domačih korenin - naj ohrani naša dolina svoj podedovani obraz! Videm-Dobrepolje.

Helmeringhausen, 2014. Medmrežje: http://www.helmeringhausen.de/ (29.12.2014).

Ilešič, S. 1959: Die Flurformen Slowenines im Lichte der europäischen Flurforschung. Münchner geographische Hefte 16.

Kladnik, D. 1999: Leksikon geografije podeželja. Ljubljana.

Klemenčič, M. M. 1995: Krajevna identiteta na primeru srednje in zgornje Gorenjske. Dela 11.

Klemenčič, M. M. 2003: Civilizacijske razvojne stopnje in razvojni problemi obrobnih območij v Sloveniji. Dela 19.

Klemenčič, M. M. 2006: Teoretski pogled na razvojne strukture slovenskega podeželja. Dela 25. DOI: http://dx.doi.org/10.4312/dela.25.13.159-171 
Klemenčič, M. M. 2010: Podeželska idila ali koma slovenskega tradicionalnega podeželja. Podeželje na preizkušnji - jubilejna monografija ob upokojitvi izr. prof. dr. Antona Prosena. Ljubljana.

Klemenčič, M. M., Lampič, B., Potočnik Slavič, I. 2008: Življenjska (ne)moč obrobnih podeželskih območij v Sloveniji. Ljubljana.

Knežević Hočevar, D., Černič Istenič, M. 2010: Dom in delo na kmetijah - raziskava odnosov med generacijami in spoloma. Ljubljana.

Logar, E. 2013: Sodobne razvojne smeri polkmetov na primeru Voklega. Dela 39. DOI: http://dx.doi.org/ 10.4312/dela.39.4.67-86

Liepins, R. 2000: New energies for an old idea: reworking approaches to »community« in contemporary rural studies. Journal of Rural Studies 16. DOI: http://dx.doi.org/10.1016/s0743-0167(99)00042-x

Magnani, N., Struffi, L. 2009: Translation sociology and social capital in rural development initiatives a case study from the Italian Alps. Journal of Rural Studies 25. DOI: http://dx.doi.org/10.1016/ j.jrurstud.2008.10.004

McLuhan, 2015. Medmrežje: http://www.livinginternet.com/i/ii_mcluhan.htm (4.4.2015).

Mlinar, Z. 2012: Globalizacija bogati in/ali ogroža? Ljubljana.

Nehden, 2014. Medmrežje: http://www.nehden.de/ (29.12.2014).

Pletziger, S. 2014: Pogovor o izboru ustnih in pisnih virov v naseljih Sögtrop, Nehden in Helmeringhausen (osebni vir, 20.10.2014). Bestwig.

Podjed, A. 2014: O življenju na Olševku po koncu druge svetovne vojne (osebni vir, 23. 5. 2014). Olševek. Potočnik Slavič, I. 2010: Endogeni razvojni potenciali slovenskega podeželja. GeograFF 7. Ljubljana.

Potočnik Slavič, I. 2013: Izbor ustreznih slovenskih naselij (19. 12.2013). Ljubljana.

Predoslje: vas z razgledom, 2014. Medmrežje: http://www.ks-predoslje.si/ (29. 12.2014).

Razpotnik Visković, N., Seručnik, M. 2013: Ugled kmečkega poklica in polkmetov v slovenski družbi po drugi svetovni vojni. Geografski vestnik 85-1.

Rebernik, D. 2009: Osnove fizične geografije Evrope. Ljubljana.

Rebernik, J. 2014: O življenju na Šenturški Gori po koncu druge svetovne vojne (osebni vir, 4. 5. 2014). Šenturška Gora.

Rigg, J. 1994: Redefining the village and rural life - lessons from South East Asia. The Geographical Journal 160-2. DOI: http://dx.doi.org/10.2307/3060071

Rowles, G. D. 1988: What's rural about rural aging? An Appalachian perspective. Journal of Rural Studies 4-2. DOI: http://dx.doi.org/10.1016/0743-0167(88)90029-0

Rutten, R., Westlund, H., Boekema, F. 2010: The spatial dimension of social capital. European Planning Studies 18. DOI: http://dx.doi.org/10.1080/09654311003701381

Sögtrop, 2014. Medmrežje: http://www.schmallenberg-soegtrop.de/ (29.12.2014).

Stepmap, 2015. Medmrežje: http://www.stepmap.de/landkarte/stumme-karte-mitteleuropa-1136239 (4. 5. 2015).

Svendsen, G. L. H. 2006: Studying social capital in situ - a qualitative approach. Theory and Society 35. DOI: http://dx.doi.org/10.1007/s11186-006-6780-3

Svendsen, G. L. H., Sørensen, J. F. L. 2007: There's more to the picture than meets the eye - Measuring tangible and intangible capital in two marginal communities in rural Denmark. Journal of Rural Studies 23-4. DOI: http://dx.doi.org/10.1016/j.jrurstud.2007.01.008

Škrjanc, R. 1999: Poleti suha in zaudarjajoča - neurejena struga potoka Belce. Gorenjski Glas 52-78 (1.10.1999).

Topographischer Atlas Nordrhein-Westfalen. Landesvermessungsamt Nordrhein-Westfalen. Düsseldorf, 1968.

Urbanc, M. 2002: Kulturne pokrajine v Sloveniji. Geografija Slovenije 5. Ljubljana.

Vas Olševek, 2014. Medmrežje: http://olsevek.si/ (29. 12.2014).

Vereinsgesetz, 2014. Medmrežje: http://www.gesetze-im-internet.de/bundesrecht/vereinsg/gesamt.pdf (29. 12.2014). 
Woods, M. 2011: Rural. Abingdon.

Woods, M. 2005: Rural Geography - Processes, Responses and Experiences in Rural Restructuring. London.

Zakon o društvih. Uradni list Republike Slovenije 61/2006. Ljubljana.

Zavrl Žlebir, D. 1996: V dolini pravijo: hribovcem privoščimo asfalt. Gorenjski Glas 49-67 (25. 8. 1996).

Ustava Republike Slovenije. Uradni list Republike Slovenije 75/2016. Ljubljana.

Zakon o lokalni samoupravi. Uradni list Republike Slovenije 94/2007. Ljubljana.

\section{Summary: (In)visible changes of rural communities: examples from Gorenjska region (Slovenia) and Sauerland (Germany)}

(translated by Irma Potočnik Slavič)

Socioeconomic development has heavily impacted the structure and (in)visible changes in all six surveyed rural communities (in Gorenjska region, Slovenia and in Sauerland, Germany):

- modernization of life and work is evident in rural practices, representations of the rural and in rural localities themselves (Halfacree 2006);

- increased heterogeneity of permanent and temporary residents and their various lifestyles contribute to complex geographic migrations;

- lives of the rural are more dynamic, bifurcated, fluid, and less bounded with the local territory, etc.

The above mentioned (in)visible changes of rural communities have generated the shift from established structures and traditional forms of socializing and cooperation (Woods 2005).

Integrated and holistic analysis of selected case studies (representative three villages in every country) required the implication of several methods: (1) quantitative statistical methods resulted in employment of tangible and intangible indicators of rural community change; (2) 30 in-depth interviews with relevant stakeholders were analysed with atlas.ti to reveal the ways in which meanings of rural community are produced, reproduced and challenged (Liepins 2000), and also the ways in which community is practiced and performed; (3) geography and structures of rural communities were mapped and explored, and consequently graphically modelled; (4) we surveyed available historical resources addressing the time dimension of rural community change.

The comparison of rural communities in both countries did not point out solely identical or at least very similar impacts of socioeconomic development on socializing and cooperation. The analysis of historical resources and interviews indicated that the life of surveyed rural communities in agrarian developmental stage (respecting the local socioeconomic and cultural circumstances) was quite similar: the inhabitants of the rural community were closely connected mostly because of economic cooperation. Major changes between rural communities in comparison occurred during the period of industrialization: in Germany, the process of farm industrialization took place, while in Slovenia small agrarian structure was maintained due to the important role of off-farm diversification opportunities and parttime farming. Nevertheless, socializing and cooperation in surveyed rural communities had become less intensive and loose. At the same time, several established forms of socializing and cooperation were detected, i.e. the persistent and leading role of firemen associations in Slovenia and shooting associations in Germany. In the information development stage, contemporary and future orientations of interviewees regarding rural community development are considerably more heterogeneous. One has to take into the consideration that in the surveyed rural communities the willingness for socializing and cooperation remains, but the motives for socializing and cooperation have been changed and are becoming very divergent and detached towards the established forms; the latter brings important challenges for decision-makers and future policy orientations. The empowerment and development of rural communities have to be based on understanding the key developmental processes, but also traditions, rituals, novelties, and alternatives must be considered with the opinions and wishes of local 
community residents. The future development of rural communities, therefore, depend on their resilience to adapt to change, and the willingness and ability to change as well.

Changes in surveyed Slovenian rural communities have to be evaluated also from the part-time farmers 'perspective. Their multifunctional role in rural communities (as agricultural producers, responsible for the maintenance of cultural landscape, users of various services in rural areas, etc.) has been constructed in the course of time with their proficient linking of regular employment (often outside the place of residence), land ownership, more or less active and market-oriented agricultural activity, participation in the farmers' cooperative, in addressing the measures of Common Agricultural Policy and networking within their social group (Razpotnik Visković in Seručnik 2013). Consequently, their inner differentiation (Logar 2013), i. e. the part-time farmers as entrepreneurs, self-sustained and marketoriented part-time farmers, aged part-time farmers, has quite frequently reflected in setting-up of several development cores: the later have generated various initiatives, which have/have not been broadly accepted within the rural community. 